\title{
Uma educação poética: João Cabral de Melo Neto
}

Adilson Citelli

Professor livre-docente no Departamento de Comunicações e Artes da ECA-USP e chefe do Departamento de Comunicações e Artes.

E-mail: citelli@uol.com.br

Para Maria Lourdes Motter

João Cabral de Melo Neto nasceu no Recife, em 9 de janeiro de 1929, e morreu no Rio de Janeiro, em 9 de outubro de 1999. Seguiu carreira diplomática servindo em vários países. Ao lado de Manuel Bandeira e Carlos Drummond de Andrade, formou uma linhagem de poetas que imprimiriam marcas e ritmos diferenciados à poesia brasileira, dando-lhe destaque no contexto da produção literária do século XX.

Talvez com exceção de seu livro de estréia, a Pedra do Sono, de 1942, a obra de João Cabral caminhou para constituir um projeto literário singularizado pela precisão tanto das formas expressivas como dos ajustes temáticos dispostos na arquitetura geral do discurso poético. No livro O Engenheiro, de 1945, vêem-se as recorrências entre o fazer do poema e o processo de construção dos edifícios:
A luz, o sol, o ar livre envolvem o engenheiro.
$\mathrm{O}$ engenheiro sonha coisas claras:
superfícies, tênis, um copo de água.
O lápis, o esquadro, o papel;
o desenho, o projeto, o número:
o engenheiro pensa o mundo justo,
mundo que nenhum véu encobre $[\ldots]$.

E no quase manifesto sobre a realização do poema presente na obra de 1947, Psicologia da Composição, há um registro que se afasta do andamento confessional e requisita o tom mais reflexivo do leitor:

[...] Esta folha branca

me proscreve o sonho,

me incita ao verso

nítido e preciso.

Eu me refugio

nesta praia pura 


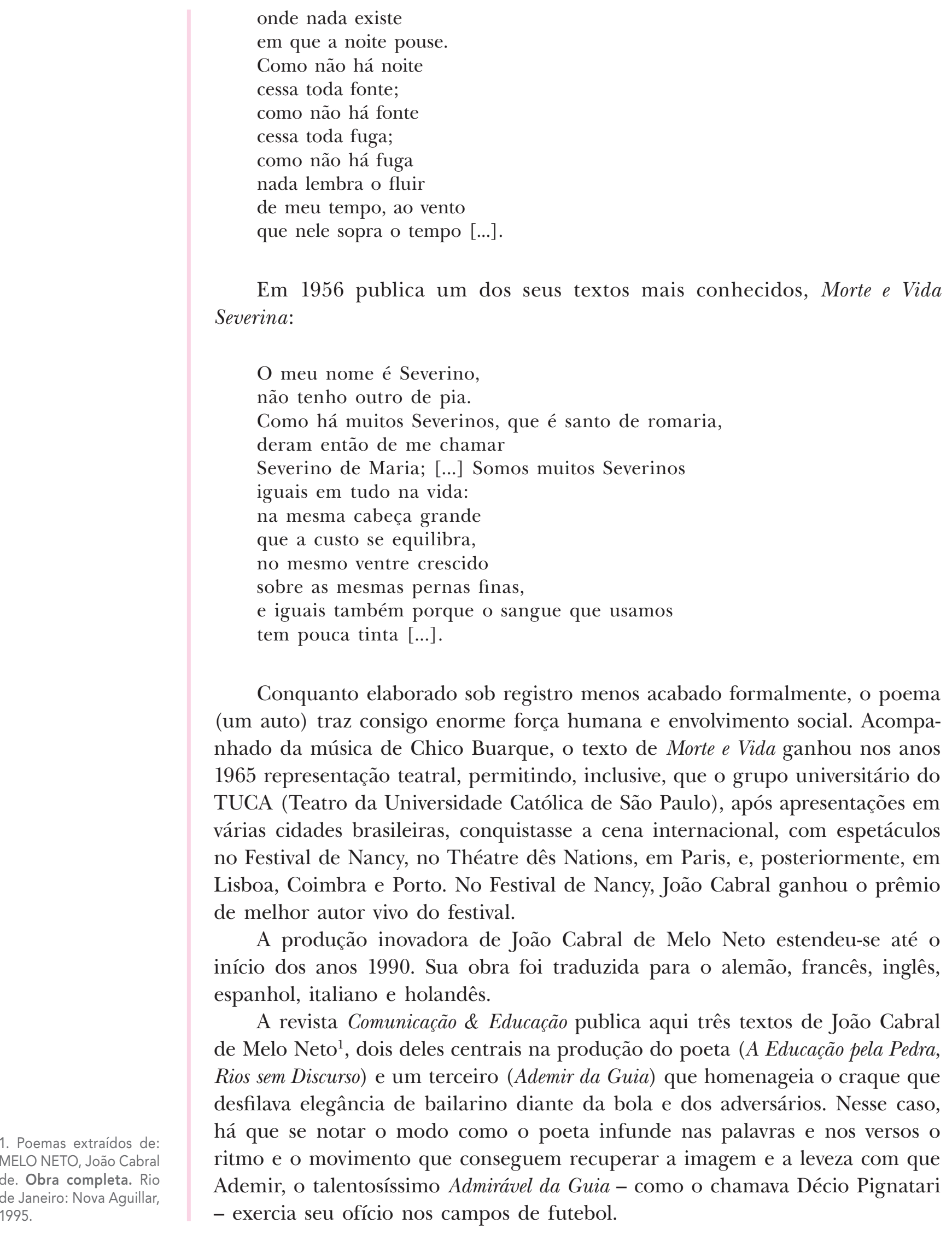




\section{A educação pela pedra}

Uma educação pela pedra: por lições; para aprender da pedra, freqüentá-la; captar sua voz inenfática, impessoal (pela de dicção ela começa as aulas). A lição de moral, sua resistência fria ao que flui e a fluir, a ser maleada; a de poética, sua carnadura concreta; a de economia, seu adensar-se compacta: lições da pedra (de fora para dentro, cartilha muda), para quem soletrá-la.

Outra educação pela pedra: no Sertão (de dentro para fora, e pré-didática). No Sertão a pedra não sabe lecionar, e se lecionasse, não ensinaria nada; lá não se aprende a pedra; lá a pedra, uma pedra de nascença, entranha a alma.

\section{Rios sem discurso}

(A Gabino Alejandro Carriedo) Quando um rio corta, corta-se de vez o discurso-rio de água que ele fazia; cortado, a água se quebra em pedaços, em poços de água, em água paralítica. Em situação de poço, a água equivale a uma palavra em situação dicionária: isolada, estanque no poço dela mesma, e porque assim estanque, estancada; e mais: porque assim estancada, muda, e muda porque com nenhuma comunica, porque cortou-se a sintaxe desse rio, o fio de água por que ele discorria.

O curso de um rio, seu discurso-rio, chega raramente a se reatar de vez; um rio precisa de muito fio de água para refazer o fio antigo que o fez. Salvo a grandiloqüência de uma cheia lhe impondo interina outra linguagem, um rio precisa de muita água em fios para que todos os poços se enfrasem: se reatando, de um para outro poço, em frases curtas, então frase e frase, até a sentença-rio do discurso único em que se tem voz a seca ele combate. 
comunicação \& educação • Ano XII • Número 3 • set/dez 2007

\section{Ademir da Guia}

Ademir impõe com seu jogo

o ritmo do chumbo (e o peso), da lesma, da câmara lenta,

do homem dentro do pesadelo.

Ritmo líquido se infiltrando no adversário, grosso, de dentro, impondo-lhe o que ele deseja,

mandando nele, apodrecendo-o

Ritmo morno, de andar na areia, de água doente de alagados, entorpecendo e então atando o mais irrequieto adversário. 